İnan, C. (2018). Transformation of Islamic Political Parties in Turkey. Journal of Academic Perspective on Social Studies, (1), 1-10.

\title{
TRANSFORMATION OF ISLAMIC POLITICAL PARTIES IN TURKEY
}

\begin{abstract}
West and Westernization components shape the identity of modern Turkish Islamic political parties, the recent endeavors of the Islamists questioning the this historical position around the Justice and Development Party. Thus this study first, explain the historical background and identity of Turkish Islamic political parties then, research the conditions that led the Islamists to reconsider and transformation their positioning and finally concentrate identity formation on the around of conservatism and policy orientation of the ruling Justice and Development Party.
\end{abstract}

Key Words: Westernization, Islamic Political Parties, Justice and Development Party, Conservatism

\section{INTRODUCTION}

Concept of Islam engaged with politics, economy, social life to a certain degree. Both western advocates of Islam express Islam as 'din wa dawla' (faith and country) so as to assert both Islam's comprehensiveness and its basically political character (Browers, 2013). But, the notion that Islam provides some thing equal to a political ideology through its very nature is of incredibly current starting place. Even as there have been earlier movements with political projects in Islamic records, absolutely ideological information of Islam most effective develops inside the contemporary duration with the rooting of the kingdom states inside the religion.

Vali Nasr expresses that emergence and advance of Muslim Democracy as a "fact on the ground" and also it is influential over last fifteen years. Acording to him emergence and advance of since the early 1990s not only Turkey but also other Muslim majority countries like in Bangladesh, Indonesia, Malaysia and Pakistan view is that political life is through a pragmatic eye (Nasr, 2005). Put it differently, most of the Muslim society lived under similar conditions. With the rise of Muslim Democrats that they have want to associate integration of Muslim religious values like social relations, trade Islamic teaching on ethics, morality. However to be Islamic is not a solution, so that the Islamic political parties came to power by the transformation. For instance when we examine some of Muslim contries we can see; in Pakistan in 1997, the right of center but non-Islamist Pakistan Muslim League (PML) won 63 percent of the seats in parliament, marginalizing the Islamist Party, Jamaat-e-eIslami(JI), similarly, in the 2001 Bangladesh Nationalis Party (BNP) captured 64 percent of the seats in parliament to sideline Bangladesh's own JI and in Turkey in 2002, the Justice and Development Party (JDP; Adalet ve Kalkınma

\footnotetext{
${ }^{1}$ İstanbul Sabahattin Zaim Üniversitesi, İnsan ve Toplum Bilimleri Fakültesi, Siyaset Bilimi ve Uluslararası İlişkiler Bölümü, cananiinan@gmail.com, ORCID ID: https://orcid.org/0000-0002-6170-4293
} 
Partisi; AK Party) - a group with roots in the world of the Islamism but which has always denied such Islamist speciality as the demand for state enactment of shari'a- won 66 percent of the seats in parliaament (Nasr, 2005).

These examples demonstrated unambiguously religion has not a influential tool for the coming power because of this Islamist parties seem like "vital center" of politics is probable to belong neither to secularist and leftist parties nor to Islamist. Their purpose of establishment of political parties did not hold an abstract, meticulously theological and ideological harmonisation between Islam and democracy but rather than most of the Muslim world in response to the occasions and demands generated by ballot box. In general, parties take decision to come to power for these reason we can say that these decisions are pragmatic and maximize their own constituents' interest under the democratic order of the game.

Another enormous arguments of Nasr express that the rise of Muslim has depended on the interaction of several factors. One of them is that Muslim Democracy has surfaced in international locations in which democracy emerged after the military officially withdrew from politics, however remained a powerful participant factor. Military involvement in politics had three oustanding outcomes. Firstly, it restricted the Islamists chamber to maneuver. Secondly, it gave all actors an incentive to keep away from confronting the army while angling for benefit within the democratic technique. Eventually the military's meddling in politics brought about more elections, political realignments and shift in colations, accelerating and intensifying experimentation with new political formulation. In Turkey we can see that military strongly supported secularism due to this reason Turkey's Islamist learned to adopt pragmatic policies to avoid the generals and they learned to live together under a roof. Each the JDP and the PML sought tolessen army pressure on politics via a readiness to compromise with the generals in addition to via efforts to construct broader coalitions that the generals could hesitate to confront. Secondly, Muslim Democracy has emerged in the societies where there is a strong private sector. In Turkey, the fulfillment of JDP's Muslim Democratic platform is much less a triumph of spiritual piety over Kemalist secularism than of an importial bourgeoisie over a centralizing state. In addition to the military dynamic and economic dynamic a third motor of Muslim Democracy appears to be the lifestyles of sturdy opposition over votes. Like many other parties Islamic parties adopt the pragmatic act to come power.

The competitive elections made every day led either spiritual parties to pragmatism and put the other parties into extra attentive attempts to symbolize Muslim values. The conspicuous impact is to praise moderation. The game is to win the middle. This is the politics of what electoral specialists call "the median voter" round whose position on the issue spectrum majorities cluster. In the Turkey Ekmeleddin İhsanoğlu is the most substantial examples of competitive elections. If Deniz Baykal showed a candidate we did not see competition in this election.

According to Nasr case of Turkey on the politics and Islam show that struggle between Islamist and military since 1990s. In these processes during early 1980s and until today we can see new term in political arena these consist of Islamist, consertavive democratic, politics of services, Islamic bourgeoise. When we look at these processes, we see that end of about of direct military rule in the early 1980s had opened the door for Islamists to go into politics. In 1987, Necmettin Erbakan prepared the Welfare Party (WP; Refah Partisi; RP) to marshal Islamist help some of the lower and lower-center classes in addition to the booming unbiased non-public area. By means of 1994, the WP was winning municipal races in Istanbul and Ankara. A year later, it took 22 
percentage of the vote in the countrywide parliamentary elections. In 1996 WP constituted a governing coalition with the secular the True Path Party. Erbakan became prime minister of the coalition government. The Turkish Armed Forces (TSK), lengthy the fierce keeper of Kemalism's secular nationalist flame, was now not reconciled to an islamist ascendancy. Beginning in early 1997, the generals launched steps of a "postmodern coup" (Nasr, 2005) manipulating the courts and parliamentary manner to upend Erbekan's government. The RP determined itself under a formal ban for transgressing the constitution's secularist red lines. Some of the Virtue Party (VP; Fazilet Partisi; FP)'s activists attempted to prepare a brand new formation referred to as distinctive feature political parties, however in 2001 that too was banned. Right-wing and mainly nationalist parties stepped into the resulting gap by along with appeals to standard Muslim values in secular platforms. The importance of this course has never disappeared for Islamic politicians. The military's politico-juridical strike towards the Islamists split the Muslim values bloc. In 2002, a collection of more youthful Islamist politicians beneath Erdoğan -the one time mayor of Istanbul who had simply served a prison term on prices of inflaming non secular passions- broke with Erbakan to form the AKP, leaving the distinctive feature Virtue Party's traditional-Islamists rump to rename itself the Felicity Party. The November 2002 elections had been an AKP romp, as the element gained a clean plurality of the famous vote and a massive majority of the seats in parliament. The Fecility Party (FP; Saadet Partisi; SP) received a scant 2.5 percent of the vote nationwide, nicely short of the ten percentage needed for parliamentary representation.

As we know most of the members of AKP belonged to the Welfare and Virtue Party and also they are also middle-class and lower-middle-class elements and their history did not related to Islamist thouhgt.

Transformation of the Turkish Islamic movement according to M. Hakan Yavuz's arguments focus on the meanings of Justice and Development Party "uncontaminated" or "pure" party to differentiate itself from the alternative political parties (Yavuz, 2006). The JDP turned into positive within the 2002 country wide elections because it moved to the middle of political spectrum and citizens seemed this shift as credible and fantastic. Given its islamic roots and the past ties and statements of its leaders, the party applications, boom and conquest of electricity in Turkish politics merits attention. The transformation of Islamic motion inside the form of moving from oppositional to propositional is an outcome of underlying adjustments in Turkish society, mainly modifications inside the new commercial enterprise elegance and new intellectuals. Despite the fact that the pressures put on the JDP to undertake adjustments to fulfill the Copenhagen Criteria for European Union (EU) membership are crucial, they're insufficient to fully provide an explanation for the JDP's path of alternate. It's miles a sociological error to lessen the compass of political change solely to the Copenhagena Criteria. In this feel the JDP is not the cause the silent revolution going on in Turkey, however alternatively the outcome. The high agent of of this variation is enterprise class developed as a result of Prime Minister Turgut Özal's neoliberal economic revolution. The second key agent is the new highbrow magnificence outside the manage of nation (Yavuz, 2006).

\section{Components of Conservative Democratic Political Parties}

Although the twentieth century, liberalism, fascism, communism and socialism are known as the popular of ideologies, some thinkers see conservatism as an ideology so important that it can be compared with liberalism and socialism. However, the basic philosophy and founding principles of conservatism still remain a controversial issue. While conservative democracy supports a 
limited and defined form of political power, it does not accept oppressive authoritarian or totalitarian practices. Conservative democracy takes into account political legitimacy based on the sovereignty of the people and later on the rule of law based on the constitution and universally accepted norms. These constituents are the basis of political power, and political leaders gain legitimacy by accepting the will of the nation. Therefore, political legitimacy is based on the common acceptance of a national identity that expresses itself in the norms of action, rules and collective value (Akdoğan, 2006, p. 50).

Before the JDP comes to power Turkish politics we can not see political, economic stability for these reason that a few scholars generally tend to study the present day experiment in Turkey because the successful political integration of an Islamic motion within a democracy. Despite the fact that the JDP leadership denies its Islamic background and claims to be conservative democratic party, however the party did emerge out of the ashes of the Welfare and Virtue parties that were closed down by means of the constitutional court docket on expenses of being a forum and proponent of anti secular sports. Moreover, most of people's deputies are observant Muslim in their every day lives. For instance their spouses retain to put on headscarves, which have been banned at public officies, ceremonies and universities due to the fact they are appeared as the task to the secular nature of Turkey. With the exception these Turkey's experince with the JDP raises are bringing to some of complex questions following that; is the JDP an Islamic party, is it viable for an ex-islamic movement to come to be a Islamic or non-Islamic, is the commitment of the participants of the contributors of the JDP or the spiritual values of their personal existence enough to label the party Islamic, when does a motion or a party end up or cease to be Islamic and even if the management of the Virtue party denies any reference to political Islam are we able to nevertheless do not forget the Islamic party?

Arguments of JDP is that is free to govern the country and ignores many religious claims of its conservative constituency. And also JDP position in Turkey identified itself "the process of postIslamism or the shift from the politics of identity to the politics of services. In order to understand the origins and regulations of JDP one has to explore not handiest the social and political context of the brand new Muslim actors, that is, the Islamic bourgeoisie, but also the JDP's identity, its politics and miles dating with the Islamic political companies. It's far important to have a look at the function of the Islamic bourgeoisie gives the monetary method to develop the brand new political motion through its charities, television stations, radios and newspapers and such has boosted its social fame. These are important by virtue of these titles lead to the following questions; who are those actors, what are their identity and politics, how do they shape the orientation of the JDP and what is the position of Islamic bourgeoisie in the fragmentation, or even ultimately of Islamism?

According to Yavuz Recep Tayyip Erdoğan's new theory of politics and globalized discourse, alongside along with his charismatic personality, is in the back of his electoral achievement in November 2002. As an activist of Islamic politics the countrywide outlook motion of Necmettin Erbakan after which because the mayor of Istanbul, Erdoğan understood that political fulfillment and consolidation happens on the neighborhood level. At the local degree politics isn't always approximately huge thoughts or liberation ideologies but as an alternative approximately rendering social offerings and proving to the populace that problems of corruption and responsibility are addressed in a style markedly superior to preceding administrations. Politics, 
for Erdoğan, is ready serving and enhancing one's regular life and a practical tool to articulate the claims of humans. On the premise of his experience in Istanbul, Erdoğan became conscious that the principle source of the JDP's legitimacy is based on meeting the needs of humans and supplying social offerings to all. This attention makes him the most pragmatic chief in turkish records, and on the identical time the least ideologically devoted and primarily based this politics on a country wide scale.

\section{Historical Background of Justice and Development Party}

The most essantial independent Islamic Movement in the history of the Republic of Turkey is National Outlook Movement (Milli Görüş Hareketi). The most important feature of the National Outlook Movement is that it is both opponent and modernizing. The history of the National Opinion Movement, which is shaped between these two opposite aims, can be explained in another way by the redefinition of religion-state, legal-illegal, private-public spaces and the relocation of religion to the public sphere (Yavuz, 2004, p.591). Necmettin Erbakan was the leader of National Outlook Movement (Dağ1, 2006). He is inevitably known as the most influential Turkish Islamist politician of the twentieth century. The idea of intellectual property of National Outlook Movement were laid in 1967, and the start was given by Necmettin Erbakan and a group of his friends as independent candidates in the 1969 general elections. National Outlook's set up under same purposes and political aim various political parties; National Order Party (NOP; Milli Nizam Partisi; MNP), National Salvation Party (NSP; Milli Selamet Partisi; MSP), Welfare Party, Virtue Party and Fecility Party.

MNP is roughly composed of three social layers and one of them is mainly religious elites of provinces originating in the secular educational institutions of the republic and generally selfemployed elite. Second one of them, religious entrepreneurs engaged in trade and industry in the provinces and last one is low-income Sunni religious people living in both rural and large cities. Because of this complex structure of party some times they can face to opposite quests or expectations. Therefore, under the 'Islam brotherhood' they try to ensure the harmony, order and unity (Çakır, 2004, p. 545). The substantial positions of the NOP's were mainly tied to the Iskender Pasha Islamic Monesttary, one of the leading figures of the Nakshibendi sect in Turkey. The sect Sheikh Mehmet Zahid Kotku personally approved and encouraged the establishment of the Party. As I said above NOP was the first Islamic party in Turkey and it face to most of the issues and the most important of them is ideological uncertainty. They did not have any experience for the making of Islamist politics. More than that as we all know, the current laws were largely limiting the making of politics on an Islamist basis. Another important view is that although the objective conditions required the establishment of the party were the result of the sharpening of the functional divisions in the industrialised Turkish society, the press and the public regarded the new party and its rulers as the supporter of Islam in Turkey through political means (Sarıbay, 2004, p. 576).

The common feature of NOP policies are to create a type of believer who will take part in social life and economic activities and give importance to moral imperative. The NOP saw the heavy industry as the guarantee of political and economic independence. In this context, advocates the publishing of a new Industrial Incentive Law to ensure industrialization. In the First Grand Congress, Erbakan expressed the fundamental changes in NOP's economic meaning as follows. 
Changing the system that finally installs the tax to the poor, saving our people and our economy from the damages of exploitative interest, prevention of waste, development of new systems that will benefit from soil maximum, creation of a spirit to work with the love of worship and introduction of national values by returning to national tourism.

When we came On May 20, 1971, the NOP was closed by the Constitutional Court because it went beyond the political system of the borders of the Kemalist ideology based on Articles 101, 92, 94 and 97 of the Political Parties Law. Following the closure of the NOP, National Salvation Party was established on October 11, 1972. The important question for the establishment of the NSP is whether there is any difference between the NOP; if so, where these differences are gathered. But as we know both founding leader of NOP and NSP are same. This shows that the NSP is an unmodified continuation of the NOP. The Constitutional Court begun to act more cautiously on the NSP executives in order to avoid the same result because of the closing of the NOP. So that Erbakan, who was the president of the closed NOP, was not even among the founders of the new party. When we look at the five main objectives of NSP; inner peace, state nation integration, great Turkish torch again (yeniden büyük Türkiye meşalesi), spiritual development and material development (Saribay, 2004, p. 581). With these aims we can show that clearly similarities between NOP and NSP. In the late 1970s, radical Islamic movements in the entire Islamic world developed and increased and Turkey was under the influence of this radical wave. At this very moment, the Kudüs Mitingi organized by the party in Konya shows radicalization impact. Briefly after the Konya Mitingi, the army seized the administration on September 12, 1980 and the coup have tried the party leaders at the martial law court. After the 12 September junta allowed political parties, 33 people under the chairmanship of attorney Ali Türkmen founded the Welfare Party on July 19, 1983. But because of the junta veto, the WP failed to gain the right to participate in the general elections. It would have to wait for the political ban to be lifted and Necmettin Erbakan to be elected to the Second Congress of the WP in October 1987.

In the first elections, the WP did not pass the election threshold with a 7.1 percent rate and could not get Parliament deputies. In all elections since then, the WP had increased its votes. WP achieved its greatest success by winning 19,1 percent of the general municipalities in the 1994 local elections, winning many mayors of large provinces (Sarıbay, 2004, p. 596). The party that defined the worldview as a national opinion was both conservative, nationalist, and Islamic. The biggest difference between the NSP and the WP was that the WP had a more democratic and more civilised discourse of less religious concepts.

After the 1995 elections, the Turkish Grand National Assembly was ruled out for forming a new government, which entered as the first party. Iftar meal given by Erbakan to religious leaders, mosque debate in Taksim, Libya trip, support of WP's for headscarf action are prepared the 28 February process. The Constitutional Court closed the VP with the decision that it became the focus of anti-secular ideas and actions.

\section{Identity of Justice and Development Party}

Justice and Develoment Party is defining itself with conservative democratic rhetoric by avoiding the notion of Islam, though not exactly. First of all, in his party's founding meeting Erdoğan described JDP as a party defending the democratic and secular state of law, considers secularism 
the basic principle of the guarantee of democracy and social peace, and in search of a permanent social consensus around the basic principles of the Republic (Akdoğan, 2004, p 625). Secondly, when we look at the JDP's politics of ground, we see that pragmatism is dominant rather than thinking; we can say that discourse is based on national values and economic development JDP's political project has not yet occurred. Applied political project is the Copenhagen Criteria, including the demands of the European Union; while the economic program is the agreements remaining from the International Monetary Found ( IMF) and the Kemal Derviş period.

Even though the JDP leadership denies its Islamic background and claims to be a conservative democratic party that it did not emerge out of ashes of the Welfare and Virtue Parties that were closed down by way of the constitutional court label on charges of being a forum and proponent of antisecular sports (Yavuz, 2006). In addition to this that the majority of the JDP's parliamentarians are obedient Muslims in their every day lives. When we look at the examples we can say that their wifes continue to wear headscarves although which have been banned at public offices, ceremonies and universities. However, JDP leaders often expressed value-based discourses such as universal values and human rights, democracy and free market principles. As we know these are threat of secular nature of Turkey (Y1lmaz, 2008, p. 56). Erdoğan frequently refers to the fact that his party is a conservative democratic party, while the public's visibility of religion can tolerates, but religion is not only an active part of the Islamist discourse, and it is also a cultural base. In contrast to the way of imposing an Islamist political identity on the basis of opposition to the West, JDP has consistently stressed the West's political values. At the same time party, the West, particularly the EU was seen as an important ally in the democratization of Turkey (Cinar, 2006).

Islamic political movement has changed the direction with the JDP. We can identified this process by argument of the process of post-Islamism or the shift from the politics of identity to the politics of services or well-known meaning hizmet partisi. For the understanding origins and policies of JDP we should consider social and political context of JDP, new Muslim actors, Islamic bourgeoise and JDP's politics and its relationship between Islamic groups. The variations between the political identity of the JDP and the political Islamism of the National Outlook Movement, the movement from which the JDP is taken into consideration to have developed, can also be examined. The JDP's novel political identity no longer best impacts the existing political climate in Turkey, however additionally has ability to influence and change Turkish political way of life and establishments for years yet to come. These capability future consequences can also be taken into consideration.

\section{Transformation of Justice and Development Party}

In the previous section I explained that under which conditions political parties revise their political ideas, under which conditions radical political parties would moderate, under which conditions political parties pursuing identity politics give up their emphasis on identity and try to establish catch-all political parties, under which conditions Islamist political parties revise their political discourses these questions and apart from that I gave brief stories about political parties from National Outlook Party to Justice and Development Party. Now, in this part I will discuss which of the theory explain that transformation of JDP.

As for me, because of repression on the area of not only political but also social, economical parties can go to the moderate and avoid radical discourses. As we know National Order Party, National Salvation Party, Velfare Party, Virtue Party closed because of their religious discources, 
and governmets changed by military coups. The last known example is 28 February postmodern coup. After this event WP found itself under a formal ban for transgression the secularism red lines. When we come to 2002, a group of Islamist younger politicians under Recep Tayyip Erdoğan's leadership served a party and avoided the values, discources of National Outlook Movement. The Nowember 2002 elections were resulted with victory of JDP and it take a huge majority of the seats in parliament. Although many JDP members belonged to the Welfare and Virtue Party but they are also middle-class and lower-middle-class and they have no history of Islamist ties. JDP more than two years, it has no clear political aim and electoral strategy. It also lacks a clear platform fort he role of Islam in politicis. I want to say briefly, members of JDP know that difficulty of their works. Because of they clearly know that Turkey's military would never allow to set explicitly Islamist political party and also they did not allow any party return to past Islamist party ties and come to power. This show us moderation of JDP. I think, JDP has pragmatic eye in other means, transformation of JDP is not ideological moderation it is tactical moderation. Their main purpuses win to election. Nasr said that, 'Islamist view democracy not as something deeply legitimate, but at best as a tool or tactic that may be useful in gaining the power to build an Islamic state'(Nasr, 2005). He explain that as I understand that Islam is not threat for the coming power also is a pragmatic way to come power and govern the state. He believed that pragmatic decisions to maximize the votes in the elections and it is rules of the game.

As we know that most known criticism of party which consisted of the National Outlook Movement ideas that these parties did not believe democracy and secularism. Secular side everytime has power in Turkey and they are guardian of Republic of Turkey. Threatening factors or groups which are known as the "others". Because of this, when we look at the result of the 1995 elections Welfare Party tried to be excluded from new government building efforts under the leadership of Turkish Industrialists' and Businessmen's Association (TÜSİAD) and Turkish Armed Forces (TSK) and in addition to all these press. Within a short time governmet established but government downgraded by judicial, press and TÜSİAD cooperation. But staff of JDP consisted of Recep Tayyip Erdoğan, Abdullah Gül and Bülent Arınç that they establish close relationship both global system and EU supporters in the Turkey. Because of repression JDP identify itself conservative democrat. In addition to these when we look at the politics of JDP we can say that there is no political or ideological politics and there is pragmatic politics. So, I agree with Nasr's opinion through JDP is representing middle class more than religious groups. In other words, they want to take the median voter and they avoid to radical discources and right and left ideologies that they try to stay in the middle.

Political Islam generlly known as the enemy of the West, democracy, human rights and modernity. As said all these factors between this perception JDP avoided to Islamic discources and got the moderate way. In short, JDP's imagination is shape the politics with taking support of the civil society, Turkish Army, business sector and especially people's support.

\section{Conclusion}

In Turkey, Islamist political party, religious discources, religious values are everytime can be known as the threat of secularism and red line of Turkish Republic. Firstly Turkey encounter Islamist party or movement with National Outlook Movement and their political party National Order Party by the leading of Necmettin Erbakan. He used to "national" word fort he emphasize the ummah. However not only their discources but also their religious policies not only this party 
but also National Salvation Party, Velfare Party and Virtue Party are closed down by the constitutional court.

Origion of JDP or most of the founding members of JDP came to National Outlook Movement. This is most known reality but today when we look at the implementing policies we can see great differences between them. I try to show them this reality with as I searched JDP's leaders who join a media meeting or who give interview a newspapers or TV channels. On August 14, 2001, Recep Tayyip Erdoğan, leader of the Justice and Development Party's publicity meeting in Ankara Bilkent Hotel, said that: The JDP is like Motherland Party center right party and it defines itself as a conservative democrat party and this party give importance intra-party democracy, participation and collective decision - making. Another statement that saying explicitly that coming to power in a landslide victory last year, Erdoğan styles his party as a modern conservative group based on Muslim values. He has distanced himself from former mentor Necmettin Erbakan, who founded the Islamic-influenced Welfare Party.

As we know apart from Recep Tayyip Erdoğan, Abdullah Gül we can say that Abulkadir Aksu is another foundin leader of JDP. When we look at their statement we can say that Conservatism in Turkey, especially during the Republican period, did not exist as a political thought and could not even express itself. We have only see the political framework of conservatism with the JDP. And he added that conservatism has emerged as a "tool of expression" in making the JDP's new political paradigm understandable, and as a "tool of embodiment" in its political actions, in other words, in its production of services.

Yalçın Akdoğan in his book Conservative Democracy express political philosophy of the Justice and Development Party as Conservative democracy. The Justice and Development Party aims to reproduce our indigenous and radical values system with a universal standard conservative political line, moving from our own thought tradition. According to Conservtism, politics is a field of reconciliation. The diversity and differences in the social context are recognized by government. According to JDP, the differences are natural and rich. Social and cultural diversity are political coloration on the basis of tolerance and tolerance that democratic pluralism will produce (Akdoğan, 2006, p. 10).

As a result, I ensure that JDP came to power with their new political identiy as we said above Conservative democracy. With this identity it create their policies for the taking vote every social groups like a tool in shortly. Without support of society most of the group that JDP did not demonstrate their assets. As I mentioned above elections are tool for coming power and prove its assets in the political area. I agree Nasr arguments because of arguments of him clearly show us transformation of JDP although its roots in the political Islamist National Movement in the political arena.

\section{RESOURCES}

Akdoğan Y.2004. Modern Türkiye'de Siyasi Düşünce Cilt 6- İslamc1lık. (Edt: Kollektif), İstanbul, İletişim Yayıncılık, pp. 620-639.

Akdoğan Y. 2006. The Emergence of a New Turkey (Edt: M. Hakan Yavuz), Slat Lake City, The University of Utah Press, pp. 49-65. 
Browers M. 2013. The Oxford Handbook of Political Ideologies (Edt: Micheal Freeden and Marc Stears), United Kingdom, Oxford University Press, pp. 627-643.

Cinar M. 2006. Turkey's Transformation Under the AKP Rule, The Muslim World 96, pp. 469-486.

Çakır R. 2004. Modern Türkiye'de Siyasi Düşünce Cilt 6- İslamcılık. (Edt: Kollektif), İstanbul, İletişim Yayıncılık, pp. 544-575.

Dağı İ.D. 2006. The Emergence of a New Turkey (Edt: M. Hakan Yavuz), Slat Lake City, The University of Utah Press, pp. 88-106.

Doğan Y. 2006. Muhafazakar Demokrasi, İstanbul, Alfa Yayınları.

http://www.akpartiistanbul.com/birim.asp?habergetir=1272\&birim=1

http://www.dw.com/en/turkey-offers-support-for-controversial-islamic-group/a-837905

http://www.dw.com/tr/adalet-ve-kalkınma-partisi-16-yașında/a-40072719

Nasr V. 2005. The Rise of Muslim Democracy, Journal of Democracy, 16, pp. 13-27.

Sarıbay A. Y. 2004. Modern Türkiye'de Siyasi Düşünce Cilt 6- İslamcıllk. (Edt: Kollektif), İstanbul, İletişim Yayıncılık, pp. 576-590.

Wickham C. R. 2004. The Path to Moderation, Comparative Politics, 36. pp. 205-228

Yavuz M.H. 2004. Modern Türkiye'de Siyasi Düşünce Cilt 6- İslamcıllk. (Edt: Kollektif), İstanbul, İletişim Yayıncılık, pp. 591-603

Yavuz M.H. 2006. The Emergence of a New Turkey (Edt: M. Hakan Yavuz), Slat Lake City, The University of Utah Press, pp. 1-19.

Y1lmaz İ. 2008. Influence of Pluralism and Electoral Participation on the Transformation of Turkish Islamism. Journal of Economic and Social Research 10. Pp.43-65. 